\title{
Changes in Sediment and Nutrient Storage in Three Reservoirs in the Lower Susquehanna River Basin and Implications for the Chesapeake Bay
}

\section{Importance of the Susquehanna River and Its Reservoir System to the Chesapeake Bay}

The Susquehanna River contributes nearly 50 percent of the freshwater discharge to the Chesapeake Bay in a year of normal or average streamflow. The river also transports the greatest amount of nutrients (estimates of nearly 66 percent of the nitrogen and 40 percent of the phosphorus load) from all nontidal areas in the Chesapeake Bay Basin. Excessive nutrients in the Bay result in algal blooms that decrease the amount of light reaching submerged aquatic vegetation, and upon decomposition, deplete the oxygen in the water. In a normal-flow year, the Susquehanna River also contributes about 25 percent of the sediment load from nontidal areas to the Bay. Suspended sediments also reduce light needed by submerged aquatic vegetation and can smother livingresource habitat and obstruct fish gills.

A reservoir system consisting of Lake Clarke, Lake Aldred, and Conowingo Reservoir is formed by three consecutive hydroelectric dams on the Lower Susquehanna River (fig. 1). Safe Harbor Dam, which forms Lake Clarke, was built in 1931. Holtwood Dam, the smallest of the three, was built in 1910 to form Lake Aldred. The largest and most downstream dam, Conowingo Dam, was built in 1928 and forms Conowingo Reservoir. Since construction, the reservoirs have been filling with sediment and sediment-associated nutrients. The upper two reservoirs have reached their capacity to store sediments and generally no longer trap nutrients and sediments. Conowingo Reservoir has not reached storage capacity, however, and is currently trapping about 70 percent of the

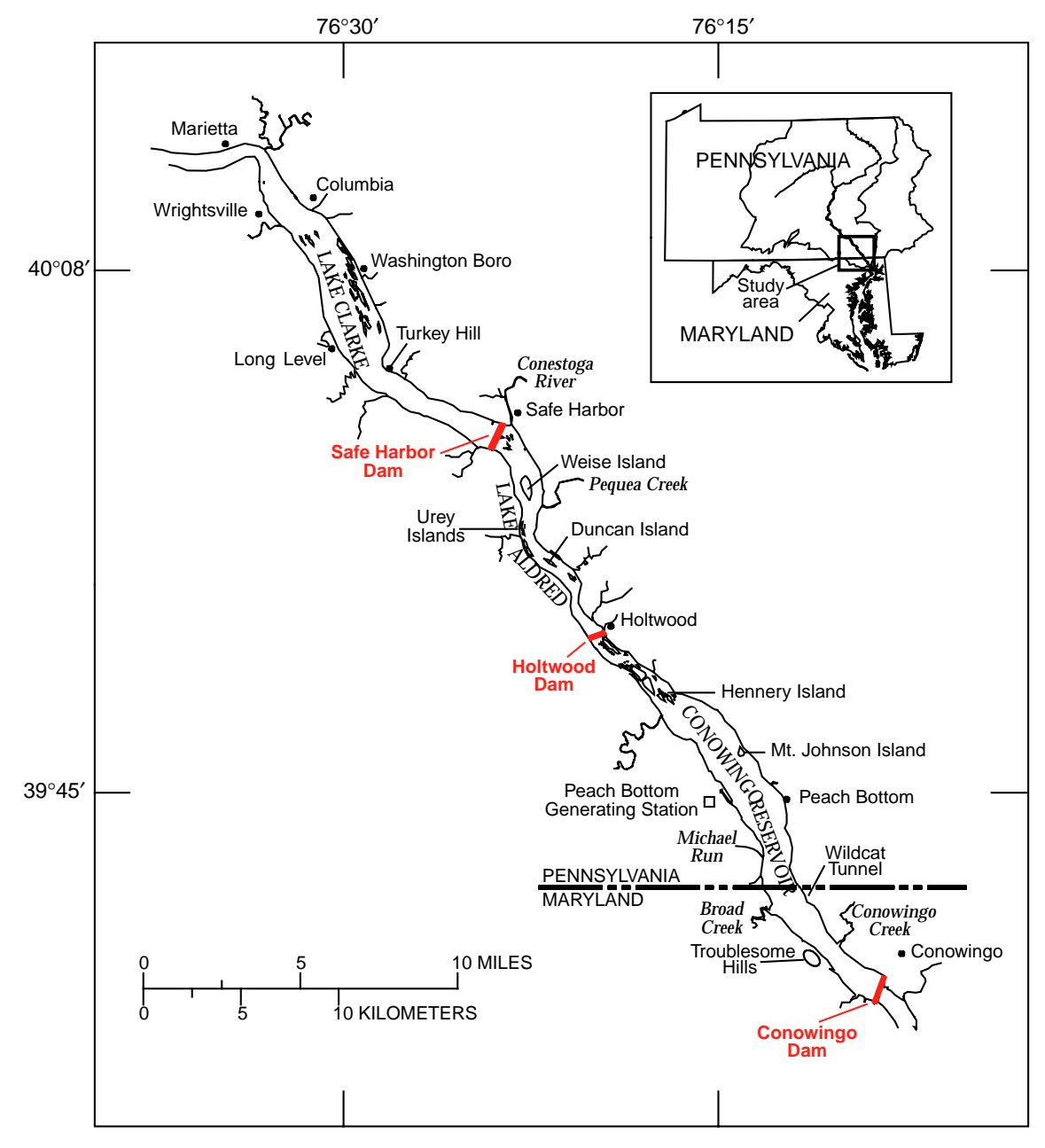

Figure 1. The location of the three hydroelectric dams and reservoirs on the Lower Susquehanna River.

suspended-sediment load, 2 percent of the total-nitrogen load, and 40 percent of the total-phosphorus load (fig. 2) that would otherwise be discharged to the Chesapeake Bay (Ott and others, 1991).

In 1990, 1993, and 1996, the U.S. Geological Survey collected information on the depth to sediment in the reservoirs to determine the remaining sediment-storage capacity in the reservoir system and to estimate when the reservoirs will reach sediment-storage capacity. In addition, sediment cores were collected and analyzed in 1993 and 1996 to determine the nutrient mass remaining in the Conowingo Reservoir. The 1996 data collection followed a major flood in the Susquehanna River Basin. 


\section{The January 1996 Flood}

January 1996 witnessed an extremely unusual and widespread flood-extensive flash flooding approached or exceeded previously recorded flood peaks in many areas of the Susquehanna River Basin (Thompson, 1996). Warm temperatures and winds, the consequent melting and runoff from 3-4 ft (feet) of snow on the ground, and an additional 3 in. (inches) of rain falling in a short time created a rapid rise in river levels. This rapid rise broke up the thick ice pack on many streams and rivers, forming many ice jams around bridges and natural obstructions in the rivers. An ice jam formed just downstream from Harrisburg, causing river levels to rise $8 \mathrm{ft}$ in 1 hour. When that jam broke, the increased flow and ice from Harrisburg and areas downstream reached a constriction in Lake Clarke, causing another ice jam to form about $2.5 \mathrm{mi}$ (miles) upstream from the Safe Harbor Dam. Behind the ice jam, the lake level rose an average of $10 \mathrm{ft}$ (the maximum rise near the ice jam was $17 \mathrm{ft}$ ), causing extensive flooding in the middle and upper parts of Lake Clarke.
When the ice jam broke in Lake Clarke, most of the backwater was released in about 2.5 hours, resulting in a surge of water and ice of approximately $180 \mathrm{Mgal} / \mathrm{min}$ (million gallons per minute). This flood surge added to an existing river flow of about $200 \mathrm{Mgal} / \mathrm{min}$. An estimated peak flow of approximately $370 \mathrm{Mgal} / \mathrm{min}$ moved through Safe Harbor Dam. The flood surge continued through Lake Aldred into Conowingo Reservoir. Operators at Conowingo Dam opened flood gates to help the surge pass. The peak flow at Conowingo Dam was about $410 \mathrm{Mgal} / \mathrm{min}$.

\section{Effect of Floods on the Reservoirs}

During floods, large amounts of nutrients and sediment are transported into and out of the Susquehanna River reservoir system. These nutrients and sediments, along with those already trapped in the reservoirs, are available for deposition, resuspension, and scour and removal from the reservoirs. Scour from the reservoirs during floods increases the remaining sediment-storage capacity. The three most recent floods-in June 1972,

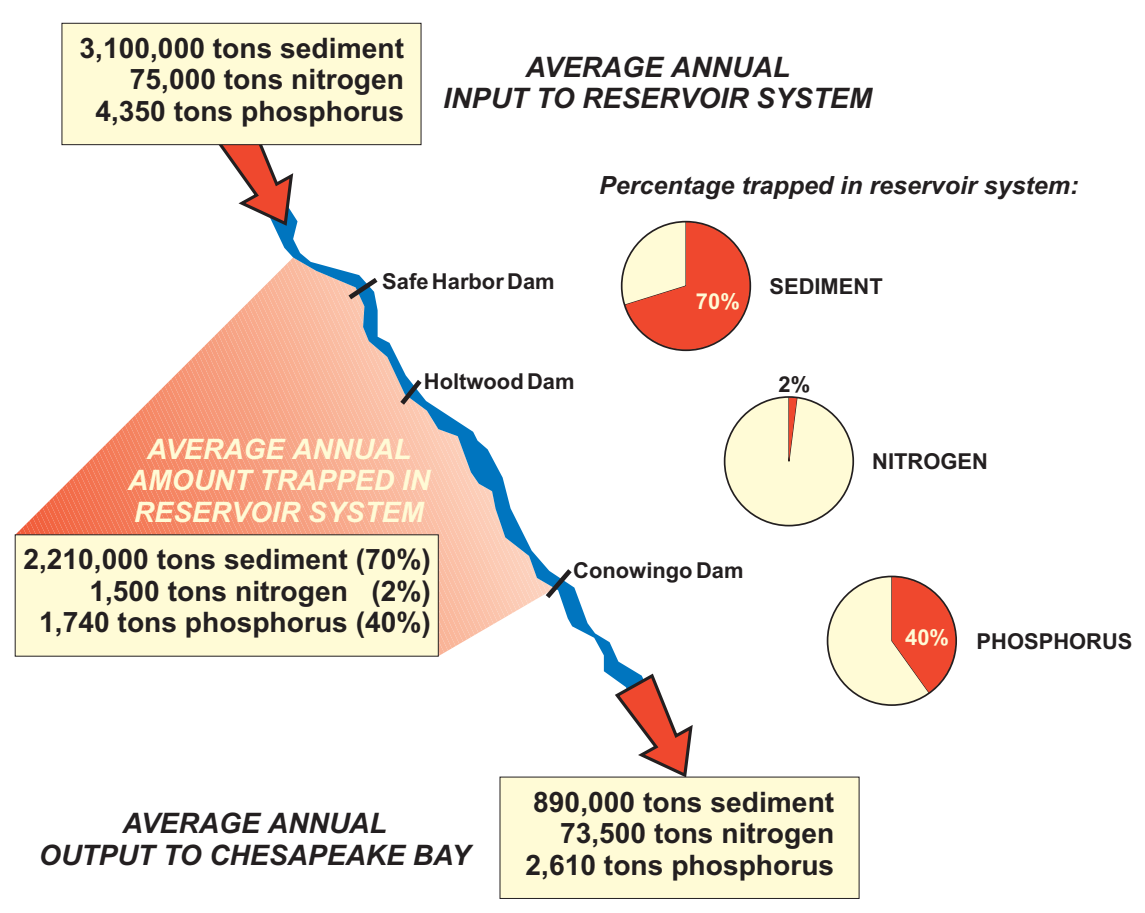

Figure 2. Average annual concentrations of suspended sediment, nitrogen, and phosphorus input into the reservoir system and output to the Chesapeake Bay.

September 1975, and January 1996removed about 36 million tons of sediment from the reservoirs.

The high flows that occurred shortly after the ice jam in Lake Clarke broke during the January 1996 flood had a major effect on storage capacities and the movement of bottom sediment in all three reservoirs. The amount of flow that causes scour of bottom sediments from the reservoirs (about $180 \mathrm{Mgal} / \mathrm{min}$ ) (Lang, 1982) was exceeded in all three reservoirs. During the flood, the amount of sediment transported through the reservoir system (3.2 million tons) and scoured from sediment trapped in the reservoir system (11.8 million tons) totaled 15 million tons of sediment delivered to the Chesapeake Bay. This is about 16 times the normal annual sediment load to the Bay. Using the average annual amount of sediment deposited in the reservoirs (2.5 million tons on the basis of data from 1959 to 1993), the amount of sediment scoured from the three reservoirs will probably be replaced by reservoir trapping in only 5 to 6 years.

Large amounts of sediment were deposited in Lake Clarke upstream from the ice jam, and even larger amounts of sediment were scoured near and downstream from the ice jam. A net amount of 2.3 million tons of sediment was estimated to have been scoured from Lake Clarke between 1993 and 1996, nearly all of it during the January 1996 flood. Sediment was deposited and scoured in many areas of Lake Aldred during the flood. However, because sediment thickness is less in Lake Aldred than in the other two reservoirs and the narrow channels preclude much sediment deposition, the net change in reservoir storage capacity and sediment mass most likely was minimal.

Sediment was deposited and scoured throughout the length of Conowingo Reservoir (fig. 3). Results from the 1996 bottom-surface survey indicate approximately 2.4 million tons of net sediment were scoured from the reservoir between the 1993 and 1996 surveys. In addition, about 6.9 million tons of sediment estimated to have been deposited between the 1993 and 1996 surveys also was scoured and removed from the reservoir. Therefore, total scour in 


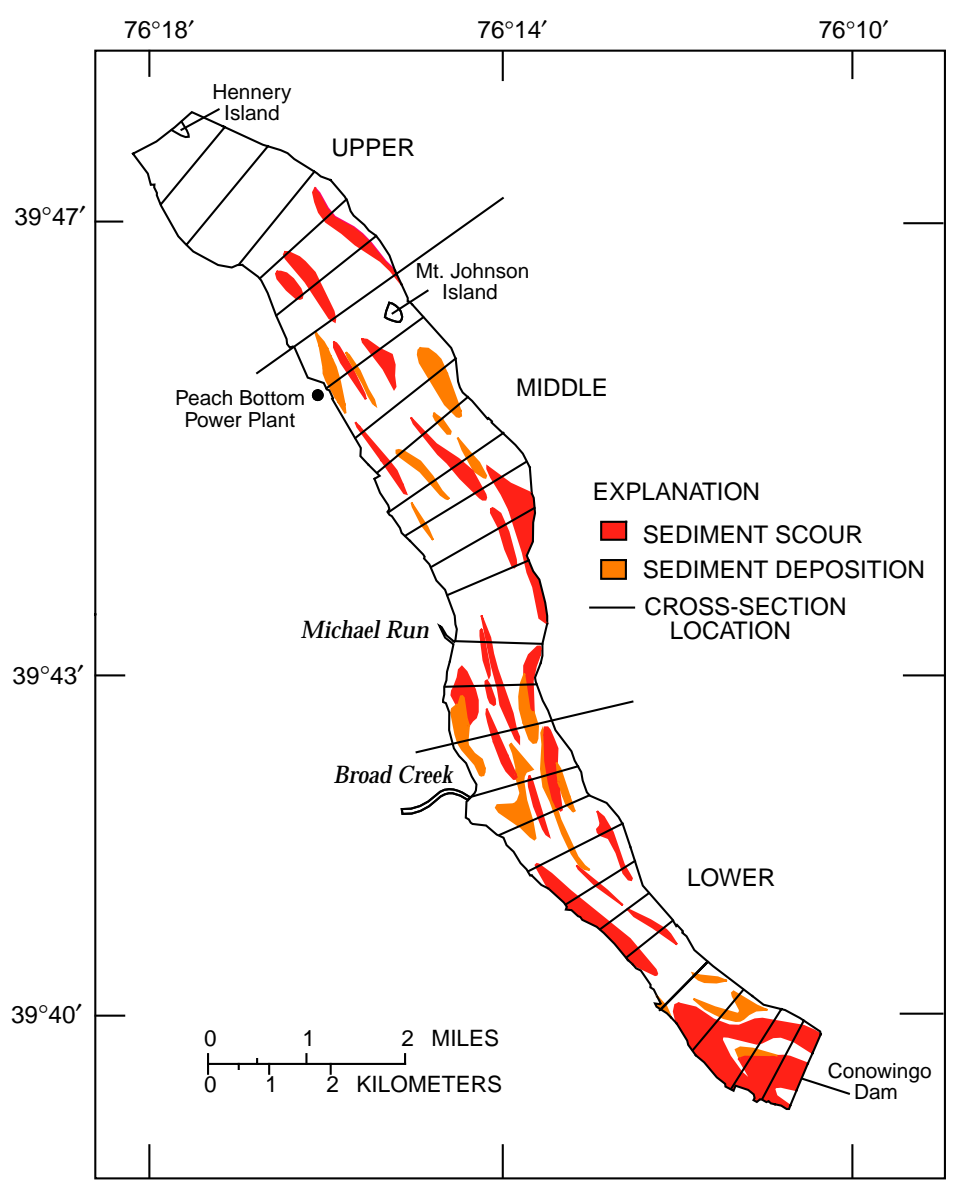

Figure 3. Estimated areas of scour and deposition in Conowingo Reservoir, 1993-96. (From Langland and Hainly, 1997.)
50 times the annual total-phosphorus load transported to the Chesapeake Bay by the Susquehanna River during a year of normal streamflow.

\section{How Much Longer Will the Conowingo Reservoir Trap Sediment and Nutrients?}

Although the Conowingo Reservoir is not filled with sediment, little space remains. Changes in the cross-sectional areas of space available for sediment and nutrient storage from 1928 to 1996 and the approximate level of maximum sedimentstorage capacity are shown in figure 4 . From the upper end of the reservoir to about $28,000 \mathrm{ft}$ upstream from the dam, the reservoir has virtually no sediment-storage capacity left, and the capacity from $28,000 \mathrm{ft}$ downstream to the dam has been greatly reduced between 1928 and 1996. As a result of scour during the January 1996 flood, sediment-storage capacity in the Conowingo Reservoir increased by approximately 1,600 acre$\mathrm{ft}$ (acre-feet), which is equivalent to 2.4 million tons of sediment. About 29,000 acre-ft remain to be filled, or 43 million tons of sediment can be deposited before reaching the sediment-storage capacity of the reservoir (shaded area on figure 4).

Estimating the time remaining until the reservoir reaches sediment-storage capacity is difficult
Conowingo Reservoir was

approximately 9.1 million tons of sediment. Slightly more than 80 percent of the total sediment scoured was from the lower third of the reservoir.

\section{How Much Nitrogen and Phosphorus are Stored in Conowingo Reservoir?}

Nutrient samples were collected from the lower third of the reservoir, where the sediment thickness is greatest. On the basis of data from Langland and Hainly (1997) and data collected from previous studies (Hainly and others, 1995; Reed and Hoffman, 1997), about 670,000 tons of total nitrogen and 130,000 tons of total phosphorus remain in the lower third of the reservoir. These amounts are equivalent to about 9 times the annual total-nitrogen load and about

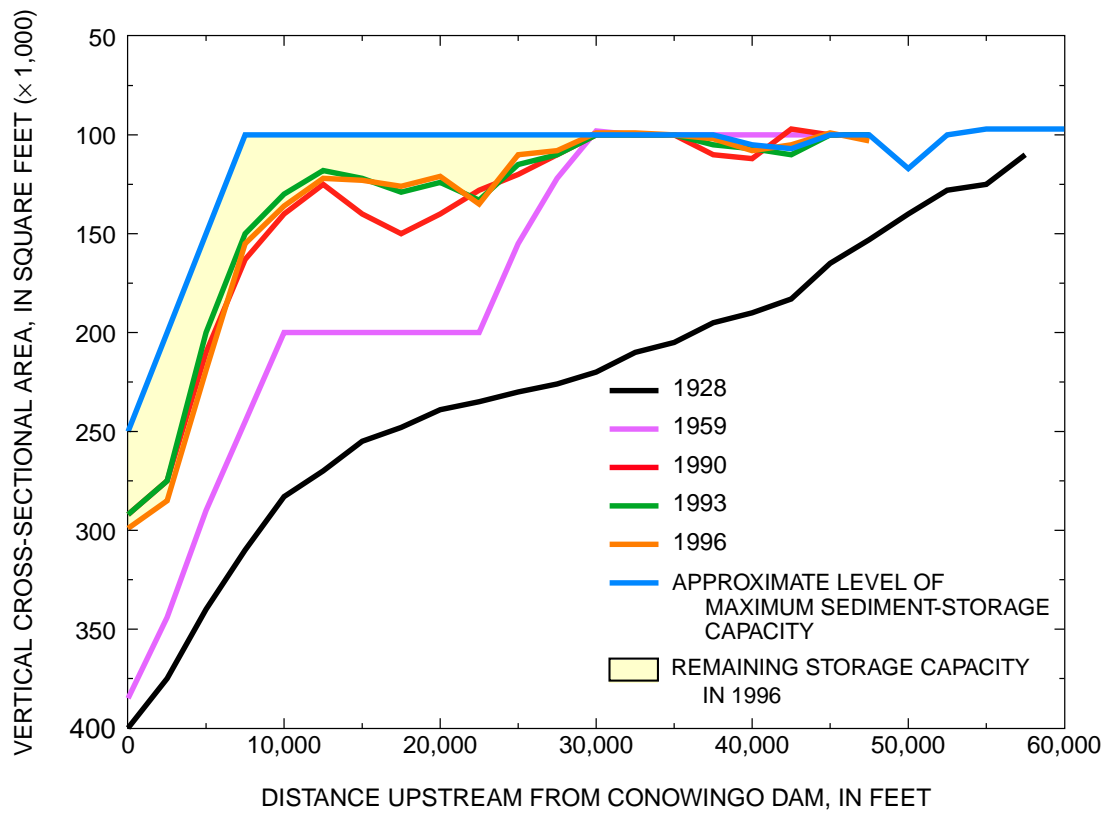

Figure 4. Changes in vertical cross-sectional area for selected years and crosssectional area at sediment-storage capacity in the Conowingo Reservoir. (From Langland and Hainly, 1997.) 
because the amount of sediment transported and deposited in the reservoirs depends on such factors as land use and management practices in areas draining to the reservoirs and the amount of rainfall in the upper Susquehanna River Basin. Occurrences of large storms that cause scour are unpredictable. Assuming a constant average storage rate of about 2.5 million tons each year (Ott and others, 1991) and no scour caused by floods, the Conowingo Reservoir could be at full sediment-storage capacity in 17 to 20 years.

\section{What Will Happen When the Reservoirs Fill?}

Once the reservoirs reach sediment-storage capacity, the sediment and nutrients being transported to the Chesapeake Bay by the Susquehanna River will likely equal those being transported into the reservoir system. If all other conditions remain constant, when the reservoirs fill, there will be a 250-percent average annual increase in the suspendedsediment load, about a 2-percent average annual increase in the total-nitrogen load, and a 70-percent average annual increase in the totalphosphorus load moving into Chesapeake Bay from the Susquehanna River Basin (Langland and Hainly, 1997). Also, after capacity has been reached, an even greater increase in the annual loads of sediment and nutrients transported to the Chesapeake Bay will occur during major scour-producing floods. It is important to note that the reservoir system will be in a state of flux with sediments because of short-term changes from storms that cause scour. Therefore, the amount of sediment transported out of the reservoir system will not always be in equilibrium with the amount of sediment transported into the system.

The Chesapeake Bay Program has set a goal of reducing controllable nutrient inputs to the Bay by 40 percent by the year 2000 . This goal for the reduction of nutrient inputs will be more difficult to meet and maintain once the reservoir system exceeds its trapping ability and, more importantly, sediment and nutrient loads delivered to the Chesapeake Bay increase.

\section{References Cited}

Hainly, R.A., Reed, L.A., Flippo, H.N., and Barton, G.J., 1995, Deposition and simulation of sediment transport in the Lower Susquehanna River Reservoir System: U.S. Geological Survey WaterResources Investigations Report 95-4122, $39 \mathrm{p}$.

Lang, D.J., 1982, Water quality of the three major tributaries to the Chesapeake Bay, The Susquehanna, Potomac, and James Rivers, January 1979 - April 1981: U.S. Geological Survey Water-Resources Investigations 82-32, $64 \mathrm{p}$.

Langland, M.J., and Hainly, R.A., 1997, Changes in bottom surface-elevations in three reservoirs on the Lower Susquehanna River, Pennsylvania and Maryland, following the January 1996 floodImplications for nutrient and sediment loads to Chesapeake Bay: U.S. Geological Survey Water-Resources Investigations Report 97-4138, 34 p., 3 pls.

Ott, A.N., Takita, C.S., Edwards, R.E., and Bollinger, S.W., 1991, Loads and yields of nutrients and suspended sediment transported in the Susquehanna River Basin, 1985-89: Susquehanna River Basin Commission Report, Publication no. 136,253 p.

Reed, L.A., and Hoffman, S.A., 1997, Sediment deposition in Lake Clarke, Lake Aldred, and Conowingo Reservoir, Pennsylvania and Maryland, 1910-93: U.S. Geological Survey Water-Resources Investigations Report 96-4048, 14 p., 3 pls.

Thompson, R.E., 1996, Statewide floods in Pennsylvania, January 1996: U.S. Geological Survey Fact Sheet 103-96, 2 p.

Michael J. Langland-1998
For further detailed information about the USGS study described here, the reader is referred to the report by Langland and Hainly (1997).

Information from the USGS on the Chesapeake Bay can be found by accessing the Activities in the Chesapeake Bay Region Home Page at http://wwwpah2o.er.usgs.gov/chesbay/

Additional information about other Federal, State, and Citizen Programs can be found by accessing the

Chesapeake Bay Information Network Home Page at http://www.chesapeake.org/

For information on USGS programs and activities in Pennsylvania, please visit our web site at http://wwwpah2o.er.usgs.gov/ or contact:

District Chief USGS, WRD 840 Market Street Lemoyne, PA 17043-1586

(717) $730-6900$

Fax: (717) 730-6997

Email: dc_pa@usgs.gov

Additional earth science information can be found by accessing the USGS Home Page at http://www.usgs.gov/

For information on all USGS products and services, call 1-800-USA-MAPS, fax (703) 648-5548, or e-mail: esicmail@usgs.gov. 